\title{
DIMENSI MODERASI ISLAM
}

\section{Abstraksi:}

Kalau kita merujuk kepada al Quran sebagai acuan ekspresi keberagamaan sama ada pada level pemahaman mahupun penerapan, maka secara eksplisit ia menegaskan eksistensi umat moderat (Ummatan Wasathan). Dengan kata lain seorang muslim moderat adalah muslim yang memberi setiap nilai atau aspek yang berseberangan bagian tertentu tidak lebih dari hak yang semestinya. Karena manusia siapa pun ia tidak mampu melepaskan dirinya dari pengaruh dan bias sama ada pengaruh tradisi, pikiran, keluarga mahupun zaman dan tempatnya, maka ia tidak mungkin merepresentasikan atau mempersembahkan moderasi penuh dalam dunia nyata. Kehadiran Islam sebagai agama adalah untuk menarik manusia dari sikap ekstrim yang berlebihan dan memposisikannya pada posisi yang seimbang. Maka dalam ajaran ajaran Islam terdapat unsur rabbaniyyah (ketuhanan) dan Insaniyyah (kemanusiaan), mengkombinasi antara Maddiyyah (materialisme) dan ruhiyyah (spiritualisme), menggabungkan antara wahyu (revelation) dan akal (reason), antara maslahah ammah (al jamaaiyyah) dan maslahah individu (al fardiyyah), dan lain lain sebagainya. Konsekwensi dari moderasi Islam sebagai agama, maka tidak satupun unsur atau hakikat hakikat yang disebutkan diatas dirugikan. Berdasarkan kenyataan diatas, maka harus ditegaskan lebih awal bahawa al-washatiyyah dalam Islam akan menjadi keniscayaan di setaip aspek yang akan dibahas di bawah ini.

Keyword: Moderat, al-washatiyyah, ta'ādul, tawäzun, manhaj

Tri Wahyudi Ramdhan

Dosen Fak. Agama Islam STAI Darul Hikmah Bangkalan wahyudi@darul-hikmah.com 


\section{A. Makna Moderat dalam Islam}

Berbicara tentang Islam, tidak dapat dilepaskan dari Alqur'an dan Hadits sebagai pijakannya. Moderat dalam Islam sering diistilahkan dengan tawassuth. Selain kata tawassuth, menurut KH. Afifuddin Muhajir, ta'ādul dan tawāzun memiliki arti yang sangat berdekatan, atau bahkan sama dengan tawassuth. Lebih lanjut, Mudir I Ma'had Aly Situbondo ini mengatakan bahwa tiga ungkapan tersebut bisa disatukan menjadi "wasathiyah". Ayat Alqur'an yang berbicara wasathiyah terdapat dalam surat $\mathrm{Al}$ Baqarah ayat 143 berikut ini,

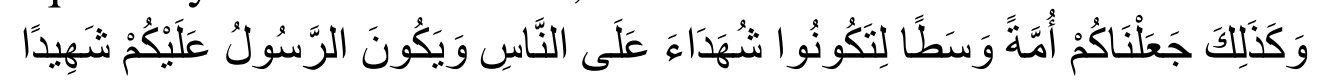

[البقرة : 143

"Dan demikian(pula) kami menjadikan kamu (Umat Islam), umat penengah (adil dan pilihan), agar kamu menjadi saksi atas seluruh manusia dan agar Rasul (Muhammad) menjadi saksi atas kamu." (QS. al Baqarah;143)

Baginda Nabi sendiri menafsiri kata وَسَ dalam firman Allah di atas dengan adil, ${ }^{2}$ yang berarti fair dan menempatkan sesuatu pada tempatnya. Memberlakukan hukum 'azimah dalam kondisi normal dan menempatkan hukum rukhshah dalam keadaan dlarurat itu adalah adil. Perubahan fatwa karena perubahan situasi dan kondisi, dan perbedaan penetapan hukum karena perbedaan kondisi dan psikologi seseorang adalah adil, dan sebagainya.

Sementara dalam hadits dikatakan,

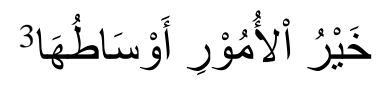

"Sebaik baik persoalan adalah sikap sikap moderat."

Mirip dengan hadits di atas adalah riwayat,

\footnotetext{
1 'Ammar Sukriy, al-Mukhtashar al-Haamm fi al-Khashaais al-Aammah li al-Islaam, (Dimisyqa: tp., 2004), Jum'at, 2 Agustus, h. 22. Bandingkan dengan: Yusuf alQardlawiy, al-Khashaish al-'Aammah li al-Islaam, (Kairo: Maktabah Wahbah, 1977), cet. I, 119.

2 Ismail bin al-Katsir al-Dimisyqiy, Tafsir al-Qur'an al-Azhim, (Kairo: Mu'assasah Qurthubah, 2000), Jilid II, cet. I, h. 112.

3 Ibnu al-Atsir, Jami' al-Ushul fi Ahadits al-Rasul, (tk.: Maktabah al-Halwaniy, Mathba'ah al-Malah, Maktabah Dar a-Bayan, 1969), Juz II, h. 318-319.
} 


\section{Dimensi Moderasi Islam}

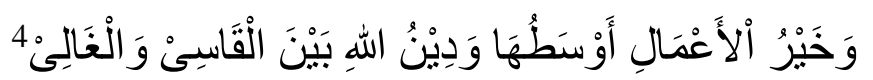

"Dan sebaik baik amal perbuatan adalah yang pertengahan, dan agama Allah itu berada di antara yang beku (konstan) dan mendidih (relatif).

Dalam ayat dan hadits di atas term moderat diungkapkan dengan kata وَسَطُ (bentuk mufrad/singular/tunggal), أَوْسَّاطٌ (bentuk jama'/plural/banyak), dan أَوَنَّن (bentuk isim tafdlill/makna lebih atau paling moderat). Tiga ungkapan tersebut berasal dari akar kata yang sama yaitu وَسَّ yang artinya tengah atau moderat. Dalam ayat dan hadits di atas hanya dinyatakan tentang watak Islam adalah moderat dalam hal bertindak (الأعمال) secara khusus seperti paparan hadits kedua, dan moderat dalam segala urusan baik, tindakan, ucapan, atau pikiran sebagaimana siratan hadits pertama. Kondisi moderat dalam segala hal inilah yang diidealkan Islam dalam firmah Allah surat Al Baqarah ayat 143 di atas.

Sunguhpun dalam ayat dan hadits di atas mengidealkan lahirnya watak moderat pada seluruh umat, namun ayat dan hadits hadits tersebut belum menjelaskan refleksi pemikiran, sikap, dan tindakan moderat yang dimaksudkan. Untuk itu, Allah subhanahu wa ta'ala dalam ayat dan surat yang lain memperjelas ayat dan hadits tersebut, antara lain firman Nya yang tertuang dalam surat Al Furqan ayat 67,

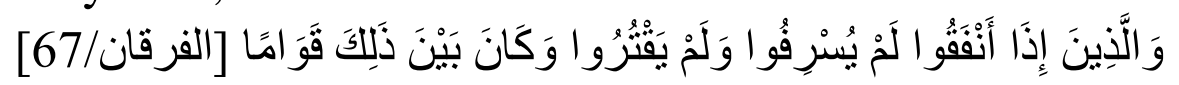

"Dan orang orang yang apabila membelanjakan (harta), mereka tidak berlebihan, dan tidak (pula) kikir, dan adalah (pembelanjaan itu) di tengah tengah antara yang demikian." (QS. al Furqan: 67)

Dalam ayat lain dinyatakan,

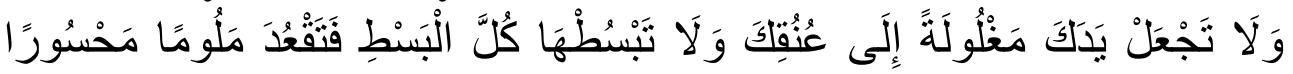

$$
\begin{aligned}
& \text { ] [الإسر اء/29] }
\end{aligned}
$$

"Dan janganlah kamu jadikan tanganmu terbelenggu pada lehermu dan janganlah kamu terlalu mengulurkannya karena itu kamu menjadi tercela dan menyesal.” (QS. al Isra': 29)

4 Jalaluddin Abdurrahman al-Suyuthiy, Jami' al-Ahadits, (Beirut: Dar al-Fikr, 1994), Juz VI, h. 226. 
Dalam firman Nya yang lain,

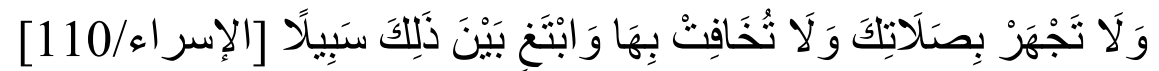

"Dan janganlah kamu mengeraskan suaramu dalam shalatmu dan janganlah pula merendahkannya dan carilah jalan tengah di antara kedua itu." (QS. al Isra': 110)

Berdasarkan tiga ayat terakhir ini, wasathiyah atau moderat berarti jalan tengah atau keseimbangan antara dua hal yang berbeda atau bertentangan. ${ }^{5}$ Dalam ayat lain, Allah berfirman,

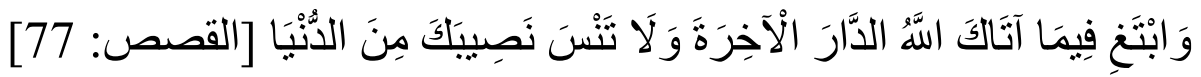

"dan carilah pada apa yang telah dianugerahkan Allah kepadamu (kebahagiaan) negeri akhirat, dan janganlah kamu melupakan bahagianmu dari (kenikmatan) duniawi....” (QS. al Qashash: 77)

Dalam salah satu hadits diceritakan tentang dialog Rasulullah dan Mu'adz bin Jabal ketika beliau hendak mengutusnya ke negeri Yaman,

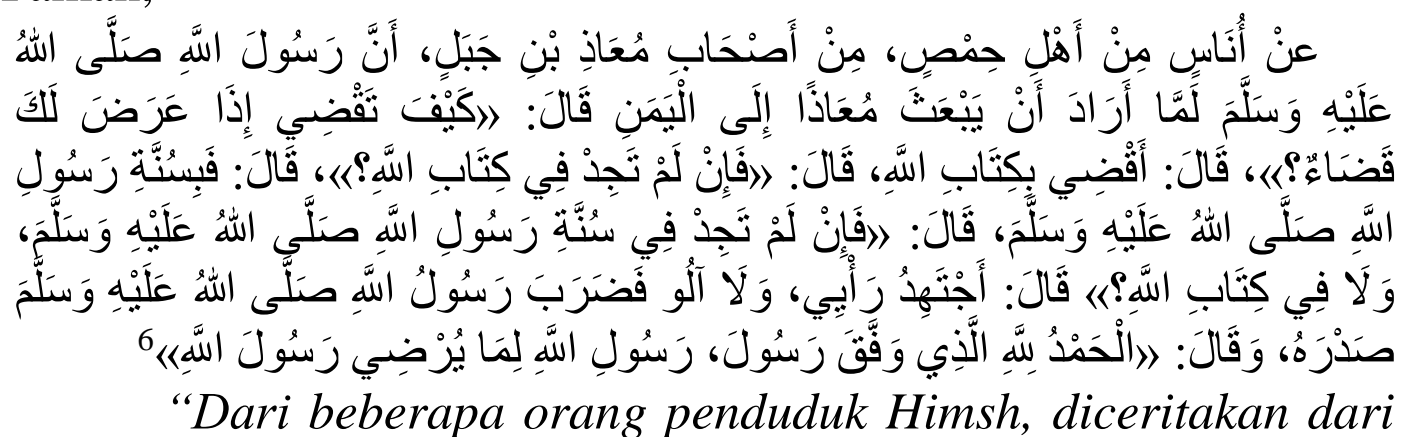
beberapa sahabat Mu'adz bin Jabal, bahwa sesungguhnya saat Rasulullah bermaksud mengutus Mu'adz untuk berdakwah ke negeri Yaman, beliau bertanya kepada Mu'adz: Bagaimana caramu memutuskan persoalan yang akan kamu hadapi? Mu'adz menjawab: saya akan memutuskannya berdasarkan Alqur'an. Nabi bertanya lagi: Jika dalam Alqur'an tidak Kamu temukan jawabannya? Mu'adz menjawab: dengan Sunnah Rasulullah. Sang Nabi pun bertanya lagi: andaikata di dua sumber itu tidak dijumpai

5 Lihat: Ibnu al-Atsir, Jami' al-Ushul fi Ahadits al-Rasul, (tk.: Maktabah al-Halwaniy, Mathba'ah al-Malah, Maktabah Dar a-Bayan, 1969), Juz II, h. 319.

6 Abu Dawud Sulaiman bin al-Asy'ats al-Sajistani, Sunan Abi Dawud, (Beirut: alMaktabah al-'Ashriyah, tt.), Juz III, h. 303. 


\section{Dimensi Moderasi Islam}

jawabannya? Mu'adz pun menjawab: Saya akan berijtihad dengan menggunakan akalku untuk menyelesaikan hal itu dan saya tidak akan ceroboh dalam berijtihad. Setelah itu, Rasulullah saw. menepuh dada Mu'adz (sebagai pertanda setuju dan bangga atas kecerdasan Mu'adz bin Jabar), seraya bersabda: Segala puji bagi Allah Yang telah memberi taufiq kepada utusannya Rasulullah (Mu'adz) sesuai yang dikehendaki oleh Rasulullah."

Berdasarkan beberapa ayat dan hadits di atas, keseimbangan atau jalan tengah (sikap moderat) antara dua hal yang berbeda mengandung dua pengertian, yaitu:

a. Moderat bukan A dan bukan B, misalnya konsep Islam tentang nafkah pada surat al Furqan dan al Isra' di atas adalah jalan tengah di antara kikir (taqtir) dan boros (israf), artinya Islam mengajarkan agar seseorang di dalam memberi nafkah tidak kikir dan tidak pula boros, melainkan ada di antara keduanya. ${ }^{7}$ Contoh lain yaitu, konsep Islam tentang paham adalah tawassuth di antara paham liberalisme dan konservatifisme. Ini artinya, bahwa Islam tidak konservatif dan tidak juga liberalis;

b. Moderat bukan hanya A dan bukan hanya B, melainkan perpaduan antar keduanya, misalnya Islam itu antara rohani dan jasmani. Maksudnya, Islam tidak hanya mengurusi masalah hal yang bersifat rohani dan tidak hanya mengurusi masalah jasmani saja, tapi mengurusi keduanya secara bersama sama. Contoh lain, Islam antara nash dan ijtihad seperti pada hadits yang menceritakan sikap Mu'adz bin Jabal di atas. Ini artinya bahwa Islam tidak hanya didasarkan pada nash semata, pun tidak hanya didasarkan pada ijtihad, tetapi Islam didasarkan pada kedua duanya secara simultan. Contoh lain lagi, Islam antara dunia dan akhirat seperti kandungan surat al Qashash di atas, artinya Islam bukan hanya mengatur urusan dunia dan bukan hanya mengatur urusan akhirat, namun Islam

${ }^{7}$ Yaitu al-karam dan al-jud (dermawan). Lihat: Isma'il Haqqiy al-Burusuwiy, Ruh alBayan al-Masyhur bi Tafsir Haqqiy, (Istanbul: Utsmaniyyah, 1331 H./1928 M.), Jilid V, Juz XV, h. 151. 
mengatur keduanya secara bersama sama. ${ }^{8}$

\section{B. Moderasi Islam dalam Berbagai Dimensi}

Fenomena wasathiyah (moderat) -sebagaimana dijelaskan sebelumnya - mewarnai ajaran aqidah, ajaran akhlak tasawwuf dan ajaran syari'ah, serta metodologinya (manhaj) di dalam kehidupan. ${ }^{9}$

1. Dimensi Aqidah

Beberapa contoh moderasi Islam dalam aspek aqidah ini dapat dilihat dalam beberapa hal berikut ini: ${ }^{10}$

a. Ketuhanan antara Atheisme dan Poletheisme

Islam ada di antara Atheisme yang mengingkari adanya Tuhan dan Poletheisme yang memercayai adanya banyak Tuhan. Artinya, Islam tidak mengambil faham Atheisme dan tidak pula faham Poletheisme, melainkan faham Monotheisme, yakni faham yang memercayai Tuhan Yang Esa. ${ }^{11}$

b. Alam antara Kenyataan dan Khayalan

Islam yang memiliki watak moderat menempatkan dirinya di antara pandangan yang tidak memercayai adanya wujud selain alam nyata dan pandangan bahwa alam ini hanyalah sebuah khayalan yang tidak memiliki hakikat wujud yang sebenarnya. Bagi Islam, alam ini merupakan sebuah hakikat yang tak diragukan, namun di balik itu, ada hakikat lain yaitu Dzat Yang Menciptakan dan Mengaturnya. $^{12}$

${ }^{8}$ Sayyid Quth, Fi Zhilal al-Qur'an, (Kairo: Dar al-Syuruq, 2004), cet. ke-33, Jilid 6, Juz 28, h. 3570. Baca juga: .Ahmad Mushthafa al-Maraaghiy, Tafsir al-Maraghiy, (Mesir: Syirkah Maktabah wa Mathba'ah Mushthafa al-Babiy al-Halabiy wa Auladih, 1946), cet. Ke-1, Juz. XXVIII, h. 101.

9 Lihat: Abdurrahman bin Muhammad bin 'Ali al-Harafi, al-Wasathiyah fi al-Islam, (tk.: tp., tt.), h. 7.

${ }^{10}$ Selengkapnya dapat dilihat pada: Yusuf Al-Qardlawi, al-Khashais al-Aammah Li alIslaam, h. 127-128.

${ }^{11}$ Selengkapnya dapat dilihat pada: Yusuf Al-Qardlawi, al-Khashais al-Aammah Li alIslaam, h. 127-128.

12 Abd al-Karim Naufan 'Abidat, Adillah al-Falasifah 'ala Wujud Allah; Dirasah Naqdiyyah, (Jami'ah Dimisyqa: Majalah, 2003), Jilid 19, Vol. I, h. 363 dan seterusnya; Abd al-Razzaq 'Afifiy, Mudzakkarah al-Tauhid, (tk.: tp., tt.), h. 11 


\section{Dimensi Moderasi Islam}

c. Sifat Allah antara Ta'thîl dan Tasybîh

Ada sebagian faham yang tidak mengakui adanya sifat bagi Allah. Menurut faham ini, Allah tidak memiliki sifat apapun, yang ada hanyalah Dzat. Di pihak lain ada faham yang menyifati Allah dengan sifat sifat yang serupa dengan sifat hawadits (makhluknya). Islam berada di tengah tengah antara dua faham tersebut, yaitu menetapkan sifat sifat yang layak bagi kemahabesaran Allah, sebagaimana tersebut di dalam Alqur'an dan al Sunnah. ${ }^{13}$

d. Kenabian antara Kultus dan Ketus ${ }^{14}$

Sejarah manusia mencatat adanya dua kelompok yang memiliki faham dan perlakuan berlebihan tentang kenabian. Ada kalangan yang mengkultus para Nabi setinggi tingginya, sehingga menyamai martabat ke Tuhan an, atau memosisikan mereka sebagai anak Tuhan; dan kalangan lain yang merendahkan martabat kenabian dengan melecehkan, menfitnah, menyiksa, dan menuduh mereka sebagai pembohong. Bagi Islam, para Nabi adalah manusia biasa yang makan, minum, kawin, dan berjalan di pasar sebagaimana layaknya manusia. ${ }^{15}$ Yang membedakan mereka dengan manusia pada umumnya adalah bahwa mereka mendapatkan wahyu dari Allah. ${ }^{16}$

e. Sumber Kebenara antara Akal dan Wahyu

Islam ada di antara kalangan yang memercayai akal sebagai satu satunya sumber dan alat untuk menemukan

13 Abd al-Razzaq bin 'Abd al-Muhsin al-Badr, Tadzkirah al-Mu'tasiy; Syarh 'Aqidah al-Hafizh 'Abd al-Ghaniy al-Maqdisiy, (Kuwait: Ghiras li al-Nasyr wa al-Tauzi', 2003), cet. Ke-1, h. 385; Muhammad Shiddiq Hasan Khan al-Qanujiy, Quthf alTsamri fi Bayan 'Aqidah Ahli al-Atsar, (tk.: tp., 1404 H.), h. 59.

${ }^{14}$ Muhammad Khalil Harras, Syarh al-'Aqidah al-Wasathiyyah li Syaikh al-Islam Ibni Taymiyyah, (Kairo: Dar al-I'tisham, tt.), h. 88-89; 'Abd al-Razzaq bin 'Abd al-Muhsin al-Badr, Tadzkirah al-Mu'tasiy; Syarh 'Aqidah al-Hafizh 'Abd al-Ghaniy al-Maqdisiy, h. 20 .

15 Abd al-Razzaq bin 'Abd al-Muhsin al-Badr, Tadzkirah al-Mu'tasiy; Syarh 'Aqidah al-Hafizh 'Abd al-Ghaniy al-Maqdisiy, h. 364-366

16 Muhammad bin 'Alawiy al-Malikiy al-Hasaniy, al-Madh al-Nabawiy Bayn alGhuluwwi wa al-Inshaf, (Makkah: Dar Wahdan, tt.), h. 5-10. Lihat juga: Abdurrahman bin Muhammad bin 'Ali al-Harafi, al-Wasathiyah fi al-Islam, (tk.: tp., tt.), h. 10-12. 
hakikat wujud, dan kalangan lain yang memandang bahwa wahyu adalah satu satunya jalan untuk mendapatkan hakikat wujud. Bagi Islam, akal dan wahyu merupakan dua hal yang sama sama memiliki peranan penting yang sifatnya komplementer (saling mendukung antara satu sama lain). Kalau diibaratkan dengan pengadilan, akal berfungsi sebagai syahid (saksi) sementara wahyu sebagai hakim, atau sebaliknya, yakni akal sebagai hakim sementara wahyu sebagai syahid, sebagaimana dikatakan al Ghazali. ${ }^{17}$

Dalam kenyataan, betapa banyak kaum intelektual yang menemukan kebenaran Tuhan dengan potensi akalnya dan kekuatan berfikirnya. Meski dalam pandangan al Ghazali, iman burhani kaum intelektual itu berada di bawah level iman wijdani para Nabi dan para wali, karena mereka melihat alam tanpa melihat Penciptanya, sedangkan para Nabi dan Rasul melihat alam dan Penciptanya (al kaun dan al mukawwin). Kata bijak mengatakan,

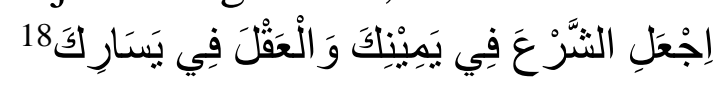

"Letakkanlah syari'at di tangan kananmu dan akal di tangan kirimu”.

Sebenarnya akal merupakan dalil al adillah (dalil bagi semua dalil), karena ma'rifat kepada Allah yang merupakan sentral kebenaran dicapai dengan aktifitas akal yang bernama nalar (nazhar), kecuali ma'rifat wijdaniyah nya nabi dan wali. Persoalannya kemudian, setelah akal menemukan kebenaran Tuhan apakah lalu mengundurkan diri dan menyerah sepenuhnya kepada wahyu? Dalam hal yang bersifat sam'iyyat yang tidak dapat dinalar dengan akal, maka akal harus taslim (pasrah sepenuhnya) kepada wahyu; sedangkan dalam hal hal lain, akal tetap punya peran dengan porsi dan kadar yang masih diperdebatkan di kalangan kaum muslimin.

${ }^{17}$ Muhammad al-Ghazali, Qadza 'if al-Haqq, (Dimisyqa: Dar al-Qalam, 1991), cet. Ke1, h. 19.

${ }^{18}$ Abu Ishaq al-Syathibiy, al-I'tisham, (Maktabah al-Taukid, tt.), juz. III, h. 408. 


\section{Dimensi Moderasi Islam}

Manusia genius yang memiliki akal besar, seperti Issac Newton, Albert Einsten, dan Max Blank, bertemu dalam satu titik tentang hakikat ketuhanan, dan hasil temuan mereka tentang sifat sifat Tuhan mirip dengan temuan kaum muslimin di dalam Alqur'an. ${ }^{19}$

Akan tetapi, beriman kepada Tuhan tidak selalu berbanding lurus dengan bergama. Artinya, orang bertuhan belum tentu beragama, dan orang yang tidak beragama belum tentu tidak bertuhan (atheis). Sebagai contoh, Kamil Plasiriun, seorang filosof, dia amat memercayai adanya Tuhan tapi tidak mau beragama, karena, seperti dikatakan Muhammad al Ghazali, agama Yahudi baginya tidak cocok dan agama Nasrani juga tidak cocok, sementara dia tidak mengenal Islam, ${ }^{20}$ atau mungkin dia telah mendengar Islam, namun Islam yang dia dengar bukan Islam yang sebenarnya, melainkan Islam yang sudah tercoreng (ter distorsi). ${ }^{21}$

f. Manusia di antara al Jabr dan al Ikhtiyar

Ada sementara aliran yang mengatakan bahwa perbuatan manusia adalah manusia itu sendiri yang menciptakannya dengan kekuatan yang diberikan Allah kepadanya, sementara golongan lain mengatakan bahwa perbuatan yang timbul dari manusia adalah di luar kemampuan dan ikhtiarnya, manusia tak ubahnya robot yang dikendalikan dan bulu ayam yang diterpa angin. Islam meyakini bahwa manusia tidak bisa menciptakan atau mewujudkan sesuatu, tetapi dia punya ruang untuk berusaha dan berikhtiar. Jadi, menurut Islam, tidak ada

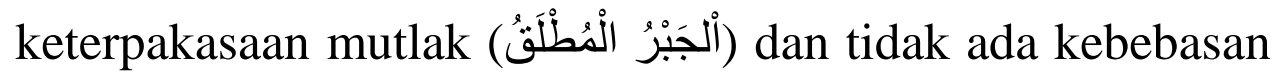

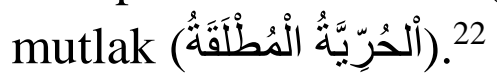

2. Dimensi Akhlak Tasawwuf

\footnotetext{
${ }^{19}$ Muhammad Ghazali, 'Aqidah al-Muslim, (Mesir: Dar Nahdlah, 2005), cet. ke-4, h. 22

${ }^{20}$ Muhammad Ghazali, 'Aqidah al-Muslim, h. 22-23

${ }^{21}$ Muhammad Ghazali, 'Aqidah al-Muslim, h. 19

${ }^{22}$ Muhammad Khalil Harras, Syarh al-'Aqidah al-Wasathiyyah li Syaikh al-Islam Ibni Taymiyyah, h. 90.
} 
Inti tasawwuf adalah takhalliy dan tahalliy, yakni membersihkan diri dari seluruh sifat tercela dan berhias diri dengan sifat sifat terpuji. ${ }^{23}$ Pada aspek akhlak tasawwuf, moderasi Islam dapat digambarkan dengan sikap tengah:

a. Antara Syari at dan Hakikat

Di dalam melihat suatu persoalan, tasawwuf tidak hanya menggunakan kacamata syari at atau kacamata hakikat saja, akan tetapi menggunakan keduanya. Karena syariat tanpa hakikat adalah kepalsuan, dan hakikat tanpa syariat merupakan omong kosong dan cenderung permissif terhadap kejahatan dan kezhaliman. Pepatah mengatakan:

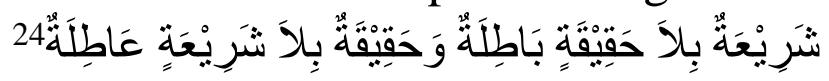

"Syari'at tanpa hakikat itu bohong, dan hakikat tanpa syari'at adalah kosong."

\section{b. Antara Khauf dan Raja}

Tasawwuf mengajarkan perlunya keseimbangan antara khauf (rasa takut) dan raja (harapan), ${ }^{25}$ karena khauf yang berlebihan bisa membuat orang gampang putus asa, sedang raja' yang keterlaluan potensial untuk membuat orang berani berbuat dosa. ${ }^{26}$ Dalam pepatah Arab diumpamakan,

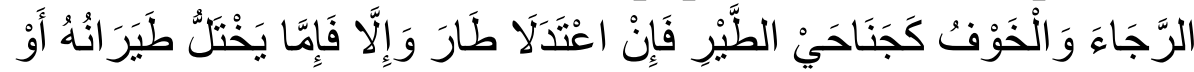

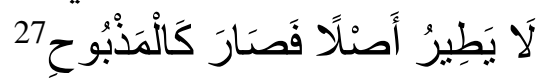

${ }^{23}$ Akhlak tentu berbeda dengan sopan santun. Yang membedakan antara akhlak dengan sopan santun yaitu terletak pada perbuatan yang dilakukan seseorang. Perbuatan seseorang dikatakan akhlak bilamana timbul secara spontanitas atau merupakan perbuatan yang sudah menjadi karakter, sedangkan sopan santun merupakan perbuatan seseorang yang dilakukan dengan penuh rekayasa

${ }^{24}$ Muhammad Nawawi al-Jawiy, Syarh Maraqiy al- 'Ubudiyyah 'ala Matn Bidayah alHidayah, (Surabaya: al-Hidayah, tt.), h. 4. Lihat pula: Sulaiman bin Muhammad bin 'Umar, Hasyiyah al-Bujairimiy 'ala al-Khathib, (Beirut: Dar al-Kutub al-Ilmiyyah, 1996), cet. ke-1, h. 12.

${ }^{25}$ Abu Usamah Salim bin 'Id al-Hilaliy, Bahjah al-Nazhirin Syarh Riyadl al-Shalihin, (tk.: Dar Ibnu Jauziy, tt.), Jilid I, h. 511-512.

${ }^{26}$ Abu al-Qasim Muhammad bin Ahmad bin Juza al-Malikiy, al-Qawanin al-Fiqhiyyah fi Talkhish Madzhab al-Malikiyyah, (Beirut: al-Maktabah al-Tsaqafiyyah, tt.), h. 284.

${ }^{27}$ Abu Sa'id al-Khadimiy, Bariqah Mahmudiyyah fi Syarh Thariqah Muhammadiyyah, (tk.: Dar al-Khilafah al-‘Aliyyah, 1318 H.), Juz II, h. 231. 


\section{Dimensi Moderasi Islam}

"Raja' dan khauf ibarat dua saya burung, jika kedua sayap itu mengepak seirama niscaya burung akan terbang, namun jika tidak demikian maka bisa saja burung itu terbang tapi tidak sempurna atau justru burung tersebut tidak dapat terbang sama sekali."

c. Antara Jasmaniyah dan Ruhaniyah

Tasawwuf dimaksudkan untuk menyucikan hati dan meningkatkan kualitas ruhaniyah, namun harus tetap memperhatikan aspek aspek jasmaniyah, seperti kekuatan fisik, kebersihan, dan kesehatan. ${ }^{28}$

\section{d. Antara Zhahir dan Bathin}

Tasawwuf memperhatikan aspek zhahir dan bathin sekaligus. Shalat -misalnya memiliki dua dimensi; format

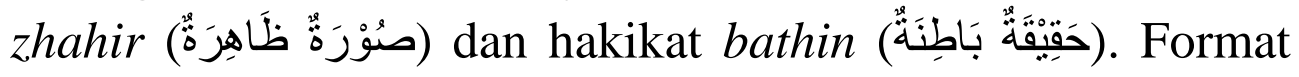
zhahir dari shalat adalah takbir, membaca fatihah, ruku', sujud, dan lain lain. Hakikat bathin nya adalah khusyu', khudhu', dan tadharru' di hadapan Allah swt. Kedua dimensi tersebut harus sama sama ditegakkan (diperhatikan). ${ }^{29}$

3. Dimensi Syari ah

Di bidang syari'ah tampak sekali terlihat sifat wasaathiyah dan keseimbangan yang menyangkut berbagai persoalan. Beberapa di antaranya adalah:

a. Syari'ah; antara Ketuhanan dan Kemanusiaan ( بَيْنَ أْلإِكِيَّةِ وَ (الْإنْسَانِيَّة

${ }^{28}$ Islam melarang penganutnya untuk terus menerus melakukan ibadah kepada Allah demi mencapai kesucian hatinya, sehingga dia melupakan anak isteri, dan kesehatan fisiknya. Hal ini digambarkan Salman al-Farisi melalui dialog singkatnya bersama Abu Darda'. Lihat: Muhammad bin 'Ali bin Muhammad al-Syaukaniy, Nail al-Authar min Asrar Muntaqa al-Akhbar, (Riyadl-Kairo: Dar Ibn al-Qayyim-Dar Ibn 'Affan, 2005), cet. ke-1, Juz 5, h. 553-554.

29 Al-Habib 'Abdullah bin 'Alawiy al-Haddad, Risalah al-Mu'awanah wa alMuzhaharah wa al-Mu'azarah li al-Raghibin min al-Mu'minin fi Suluk Thariq alAkhirah, (tk.: tp., tt.), h. 12. 
Kaum muslimin seluruhnya sepakat bahwa al Hakim hanyalah Allah swt. Ini artinya, bahwa manusia bagaimanapun tinggi ilmunya dan status sosialnya tidak memiliki hak tasyri (mensyariatkan hukum) dan tidak mempunyai otoritas tahlil dan tahrim. Sedang peran yang dimainkan para mujtahid bukanlah tasyri, melainkan upaya menggali hukum hukum Allah yang belum tampak atau masih tersembunyi di bawah permukaan sehingga menjadi ketentuan yang ready for use. ${ }^{30}$ Dari sisi ini tampak terlihat sifat ilahiyah (ketuhanan) dari hukum Islam. Dan di sisi yang lain, hukum Islam bersifat insaniyah (kemanusiaan), karena bertujuan untuk memenuhi kepentingan dan mewujudkan kesejahteraan manusia, zhahir bathin, dunia akhirat.

b. Syari'ah; antara Idealitas dan Realitas

Islam mempunyai cita cita yang tinggi dan semangat yang menggelora untuk mengaplikasikan ketentuan ketentuan dan aturan aturan hukumnya, namun Islam tidak menutup mata dari realitas kehidupan yang -justru - lebih banyak diwarnai hal hal yang sangat tidak ideal. Untuk itu, Islam rela turun ke bumi realitas daripada terus melayang layang di ruang idealitas yang hampa. ${ }^{31}$

c. Syari'ah; antara Tahlil dan Tahrim

Agama Yahudi dikenal sebagai agama yang banyak melakukan tahrim (pelarangan/pengharaman) terhadap sesuatu, sementara agama Nasrani dikenal sebagai agama yang banyak melakukan tahlil/ibahah (pembolehan),

${ }^{30}$ Wahbah al-Zuhailiy, Ushul al-Fiqh al-Islamiy, (Dimisyqa: Dar al-Fikr, 1986), cet. ke1, Juz I, h. 115.

31 Yusuf al-Qardlawiy, al-Khasha'ish al-'Aammah li al-Islaam, h. 182. Adanya perpaduan antara idealitas dan realitas ini terlihat pada struktur hukum yang terbagi pada hukum 'azimah dan rukhshah. Islam tidak memaksa umatnya untuk terus menerus menaati hukum 'azimah, tetapi dalam keadaan umatnya tidak mampu melaksanakan ketentuan hukum secara utuh, ia mempersilakan umatnya untuk mengikuti aturan hukum rukhshah. Misalnya, Islam mewajibkan umatnya melaksanakan shalat dengan cara berdiri, tetapi pada saat umatnya tidak mampu berdiri maka ia memperbolehkan umatnya untuk shalat dengan cara duduk. Lihat: Musa Ibrahim al-Ibrahim, al-Madkhal ila Ushul al-Fiqh wa Tarikh al-Tasyri' alIslamiy, (Oman: Dar 'Ammar, 1989), cet. ke-1, h. 130. Bandingkan dengan: Ibnu Qasim, Fath al-Qarib, (Surabaya: Nur al-Huda, tt.), h. 13. 


\section{Dimensi Moderasi Islam}

sehingga dalam ajaran agama Nasrani tidak terlalu banyak hal hal yang dilarang. Agama Islam datang mengambil posisi tengah tengah di antara keduanya. Artinya, dalam ajaran Islam ada tahlil dan tahrim, tetapi tahlil dan tahrim tersebut didasarkan kepada petunjuk Allah melalui utusan Nya; tidak semata mata didasarkan keputusan umatanya sendiri sebagaimana Yahudi dan Nasrani. ${ }^{32}$

Contoh lain adalah soal poligami. Dalam persoalan poligami ini, ada dua kubu yang berseberangan; satu menutup pintu poligami rapat rapat, sementara yang lain membukanya lebar lebar. Islam berdiri di tengah tengah di antara dua kutub berlawanan ini. Islam membuka pintu poligami dengan persyaratan yang tidak gampang dipenuhi sehingga tidak sembarang orang bisa memasuki pintu itu. ${ }^{33}$

Contoh ketiga dapat dilihat dalam persoalan talak. Islam, dalam talak berada di tengah tengah antara agama yang melarang talak sama sekali dan agama lain yang membolehkan talak secara mutlak. Islam membolehkan talak, tapi di saat saat kebersamaan antara suami dan istri sudah menjadi hal yang mustahil. ${ }^{34}$

d. Syari'ah; antara Kemaslahatan Individu dan Kolektif

Artinya, syari'at berorientasi pada terwujudnya kemaslahatan induktif dan kolektif secara bersama sama. Akan tetapi, kalau terjadi pertentangan antara kemaslahatan individu dan kolektif dan tidak mungkin dikompromikan, maka didahulukan kepentingan kolektif. ${ }^{35}$

32 Yusuf al-Qardlawiy, al-Khasha'ish al-'Aammah li al-Islaam, h. 138. Lihat juga: Abdurrahman bin Muhammad bin 'Ali al-Harafi, al-Wasathiyah fi al-Islam, (tk.: tp., tt.), h. 10.

33 Yusuf al-Qardlawiy, al-Khasha'ish al- 'Aammah li al-Islaam, h. 138; dan Jamal Muhammad al-Zakiy, "Ta'addud al-Zawjat fi al-Islam wa al-Diyanah al-Ukhra", dalam al-Islam wa al-Mar'ah, (Rasulullah.net., tt.), h. 12-14

${ }^{34}$ Yusuf al-Qardlawiy, al-Khasha'ish al- 'Aammah li al-Islaam, h. 138-139; dan Yusuf al-Qardlawiy, al-Halal wa al-Haram, (Kairo: Maktabah Wahbah, 1997), cet. ke-22, h. 183-184.

35 Yusuf al-Qardlawiy, al-Fiqh al-Islamiy Bayna al-Ashalah wa al-Tajdid, (Kairo: Maktabah Wahbah, 1999), cet. ke-2, h. 15-18; Muhammad Abu Zahrah, Ushul al- 
e. Syari'ah; antara Ketegaran dan Kelenturan

Artinya, dalam syari'ah ada bagian bagian yang tegar dan tak mungkin berubah dan ada bagiain bagian yang lentur dan mungkin berubah. Hal hal yang bersifat ushuliyyah (prinsip prinsip) dan maqashid (menjadi tujuan) itu tegar, sedang hal yang hal yang bersifat furu'iyyah (cabang cabang) dan wasa'il (sarana untuk mencapai tujuan) itu lentur. $^{36}$

Moderasi dengan arti memberi perlakuan yang adil dapat terlihat dalam contoh berikut ini: Pertama, contoh dari Baginda Nabi saw. Kadang beliau menerima pertanyaan dari beberapa orang penanya dengan pertanyaan yang sama dan beliau memberi jawaban yang berbeda antara penanya yang satu dengan penanya yang lain. Misalnya, beliau ditanya tentang nasihat singkat tapi padat, beliau menjawab لََغْضَبَبْ (kamu jangan marah). Kepada penanya yang lain, dengan

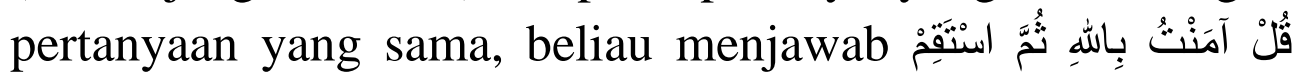
(katakanlah saya beriman kepada Allah dan tetaplah seperti itu). Dan, kepada penanya ketiga, beliau menjawab: كُفَّ عَََْْكَ لِسَانَكَ (jagalah lidahmu). Di samping itu, Nabi juga pernah ditanya tentang hukum bersentuhan (mubaasyarah) dengan isteri dalam keadaan berpuasa, dan beliau memperkenankannya. Akan tetapi, ketika suatu saat orang lain bertanya tentang masalah yang sama, beliau justru melarangnya. Ternyata diketahui bahwa yang pertama adalah orangnya sudah tua sedangkan yang kedua anak muda. ${ }^{37}$

Kedua, contoh dari Sayyidina Abdullah bin Abbas. Ada seorang laki laki datang kepada Ibnu Abbas dengan sebuah pertanyaan: " apakah orang yang membunuh orang mukmin ada taubatnya?" Ibnu Abbas menjawab: 'tidak, dia masuk neraka.' Setelah laki laki itu pergi, orang orang yang hadir

Fiqh, (Dar al-Fikr al-'Arabiy, tt.), h. 376-378; dan Wahbah al-Zuhailiy, al-Fiqh alIslamiy wa Adillatuh, (Dimisyqa: Dar al-Fikr, 1985), cet. ke-2, Juz I, h. 24.

36 Yusuf al-Qardlawiy, al-Khasha'ish al-'Aammah li al-Islaam, h. 203. Lihat juga: Wahbah al-Zuhailiy, Tajdid al-Fiqh al-Islamiy, dalam Tajdid al-Fiqh al-Islamiy, (Beirut-Dimisyqa: Dar al-Fikr, 2002), h. 172-184.

${ }^{37}$ Yusuf Al-Qardlawi, al-Khashais al-Aammah Li al-Islaam, h. 236. 


\section{Dimensi Moderasi Islam}

di situ berkata kepada Ibnu Abbas: "bukan seperti ini yang pernah engkau fatwakan kepada kami, mengapa sekarang berubah?" Ibnu Abbas menjawab: "saya yakin orang yang bertanya tadi benar benar marah dan hendak membunuh orang mukmin. Setelah diselidiki, ternyata benar benar demikian." ${ }^{38}$ Ini artinya, Ibnu Abbas membedakan antara orang yang punya potensi besar untuk membunuh dan orang yang benar benar telah membunuh.

Dari contoh contoh di atas, terlihat keadilan syari'at Islam yang merupakan salah satu dari makna wasathiyah atau tawassuth sebagai ciri khas agama ini.

4. Dimensi Manhaj

Yang dimaksud dengan manhaj di sini adalah metode istinbaath (pengambilan hukum). Watak moderasinya terlihat dalam beberapa hal:

a. Kombinasi antara nash dan ijtihad. Kombinasi ini secara eksplisit merupakan petunjuk langsung dari Nabi sebagai Shahib al Syari'ah dalam sebuah hadits dengan bentuk tanya jawab singkat antara beliau dengan sahabat Mu'adz bin Jabal.

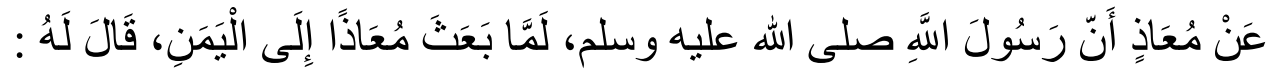

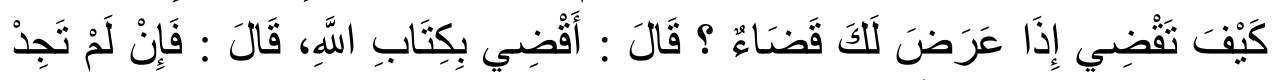

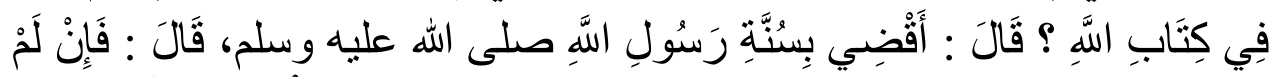

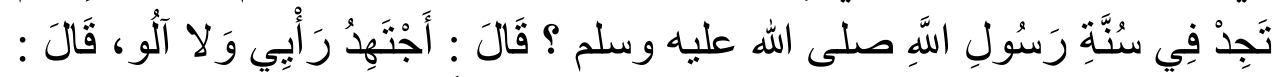

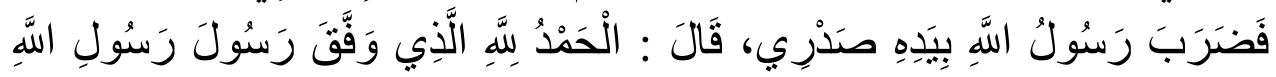

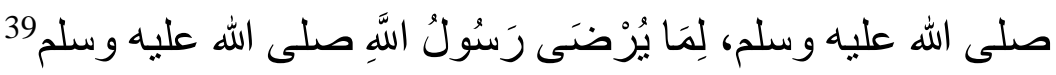

"Dari Mu'adz, sesungguhnya Rasulullah saw. bersabda kepadanya ketika beliau mengutusnya ke negeri Yaman: Bila kamu dihadapkan pada suatu persoalan, bagaimana kamu memutuskannya? Mu'adz menjawab: saya memutuskannya berdasarkan Kitabullah (Alqur'an). Bertanya lagi Rasulullah: Jika kamu tidak menemukan (jawabannya) dalam Kitabullah? Muadz menjawab: saya memutuskan berdasarkan Sunnah Rasulullah. Beliau

\footnotetext{
${ }^{38}$ Yusuf Al-Qardlawi, al-Khashais al-Aammah Li al-Islaam, h. 236.

39 Muhammad Dliya' al-Rahman al-A'zhamiy, al-Minnah al-Kubra Syarh wa Takhrij al-Sunan al-Shughra, (Riyadl: Maktabah al-Rusyd, 2001), cet. ke-1, Juz. IX, h. 33-34.
} 
bertanya kembali: jika di dalam sunnah itu tidak dijumpai jawabannya? Menjawab lagi Muadz: saya berijtihad dengan nalarku dan aku tidak teledor dengan ijtihadku. Berkata lagi Muadz: Lalu Rasulullah mengelus dadaku, seraya bersabda: segala puji bagi Allah yang telah memberi taufiq kepada utusan Rasulullah sesuai dengan yang dikehendaki (diridla'i) Rasulullah.”

Pengakuan terhadap eksistensi ijtihad secara tidak langsung merupakan pengakuan terhadap peran akal dalam istinbaath hukum. Adakalanya peran akal kecil, adakalanya besar, dan adakalanya sangat besar. Hal ini tergantung pada nash yang hendak dikaji dan kondisi persoalan yang akan dicari status hukumnya.

Lebih dari itu, adanya kombinasi tersebut merupakan konsekuensi logis dari tampilan nash nash Alqur'an dan hadits yang terkombinasi antara antara yang qath'iy dan zhanniy, serta antara kulliy dan juz'iy. ${ }^{40}$

b. Kombinasi antara Nushush al Syari'ah dan Maqashid al Syari'ah. Untuk menghasilkan produk hukum yang ideal, seorang mujtahid hendaknya mengkaji Nushush al Syari'ah dan Maqashid al Syari'ah secara terpadu. ${ }^{41}$

c. Kombinasi antara Teks dan Konteks. Seorang mujtahid tidak hanya dituntut mampu memahami nash, namun dia juga dituntut mampu memahami realitas sosial yang mengitari persoalan yang hendak dipecahkan. ${ }^{42}$ Sehingga produk hukum yang keluar tidak kaku hanya terbatas teks al-qur'an

${ }^{40}$ Muhammad bin Husain al-Jizaniy, Manhaj al-Salaf fi al-Jam'i bayn al-Nushush wa al-Maqashid wa Tathbiqatuha al-Mua'ashirah, (Riyadl: al-Mamlakah al-'Arabiyyah al-Sa'udiyyah Wizarah al-Ta'lim al-'Aliy, 2010), h. 42-43.

${ }^{41}$ Muhammad bin Husain al-Jizaniy, Manhaj al-Salaf fi al-Jam'i bayn al-Nushush wa al-Maqashid wa Tathbiqatuha al-Mua'ashirah, (Riyadl: al-Mamlakah al-'Arabiyyah al-Sa'udiyyah Wizarah al-Ta'lim al-'Aliy, 2010), h. 42 dan seterusnya.

${ }^{42}$ Muhammad Nashiruddin al-Albaniy, Sual wa Jawab Haula Fiqh al-Waqi', (OmanUrdun: al-Maktabah al-Islamiyyah, 1422 H.), cet. ke-2, h. 39. Lihat juga: Abdurrahman Zayudiy, al-Ijtihad bi Tahqiq al-Manath wa Sulthanih fi al-Fiqh alIslamiy; Dirasah Ushuliyyah Fiqhiyyah Muqaranah Tabhatsu fi Kayfiyah Tanzil alAhkam al-Syar'iyyah 'ala al-Waqi', (Kairo: Dar al-Hadits, 2005), h. 193-196. 
dan al-hadits saja atau terlalu tidak jelas karena telah melenceng dari teks yang ada.

\section{Kesimpulan}

Dari pemaparan di atas dapat kita simpulkan bahwa Islam agama yang rahmatan lil alamin mengidealkan lahirnya nilaik moderat pada seluruh umat, wasathiyah atau moderat berarti jalan tengah atau keseimbangan antara dua hal yang berbeda atau bertentangan. Hal ini terbukti dari beberapa dimensi seperti dimensi akidah, syariat, tasawuf dan manhaj yang mengajarkan dan menjabarkan nilai moderat.

Lebih dari itu, nilai wasathiyah atau moderat juga telah tercermin dalam kehidupan masyarakat muslim dan berdasarkan kenyataan diatas, maka harus ditegaskan lebih awal bahwa alwashatiyyah dalam Islam akan menjadi keniscayaan di setiap aspek kehidupan. 


\section{DAFTAR PUSTAKA}

Abd al-Karim Naufan 'Abidat, 2003, Adillah al-Falasifah 'ala Wujud Allah; Dirasah Naqdiyyah, Jami’ah Dimisyqa: Majalah

Abd al-Razzaq 'Afifiy, tt, Mudzakkarah al-Tauhid

Abd al-Razzaq bin 'Abd al-Muhsin al-Badr, 2003, Tadzkirah alMu'tasiy; Syarh 'Aqidah al-Hafizh 'Abd al-Ghaniy alMaqdisiy, Kuwait: Ghiras li al-Nasyr wa al-Tauzi'

Abdurrahman bin Muhammad bin 'Ali al-Harafi, tt, al-Wasathiyah fi al-Islam, tk.: tp.

Abdurrahman Zayudiy, 2005, al-Ijtihad bi Tahqiq al-Manath wa Sulthanih fi al-Fiqh al-Islamiy; Dirasah Ushuliyyah Fiqhiyyah Muqaranah Tabhatsu fi Kayfiyah Tanzil alAhkam al-Syar'iyyah 'ala al-Waqi', (Kairo: Dar alHadits

Abu al-Qasim Muhammad bin Ahmad bin Juza al-Malikiy, tt, alQawanin al-Fiqhiyyah fi Talkhish Madzhab alMalikiyyah, Beirut: al-Maktabah al-Tsaqafiyyah,

Abu Dawud Sulaiman bin al-Asy'ats al-Sajistani, Sunan Abi Dawud, Beirut: al-Maktabah al-'Ashriyah,

Abu Ishaq al-Syathibiy, tt, al-I'tisham, Maktabah al-Taukid

Abu Sa'id al-Khadimiy, 1318 H, Bariqah Mahmudiyyah fi Syarh Thariqah Muhammadiyyah, tk.: Dar al-Khilafah al'Aliyyah

Abu Usamah Salim bin 'Id al-Hilaliy, tt, Bahjah al-Nazhirin Syarh Riyadl al-Shalihin, (tk.: Dar Ibnu Jauziy,

Ahmad Mushthafa al-Maraaghiy, 1946, Tafsir al-Maraghiy, Mesir: Syirkah Maktabah wa Mathba'ah Mushthafa al-Babiy al-Halabiy wa Auladih

Al-Habib 'Abdullah bin 'Alawiy al-Haddad, tt. Risalah al-Mu'awanah wa al-Muzhaharah wa al-Mu'azarah li al-Raghibin min al-Mu'minin fi Suluk Thariq al-Akhirah, tk.: tp 


\section{Dimensi Moderasi Islam}

Ammar Sukriy., 2004, al-Mukhtashar al-Haamm fi al-Khashaais alAammah li al-Islaam, Dimisyqa: tp

Ibnu al-Atsir, 1969, Jami' al-Ushul fi Ahadits al-Rasul, tk.: Maktabah al-Halwaniy, Mathba'ah al-Malah, Maktabah Dar aBayan

Isma'il Haqqiy al-Burusuwiy, 1331 H./1928 M, Ruh al-Bayan alMasyhur bi Tafsir Haqqiy, Istanbul: Utsmaniyyah

Ismail bin al-Katsir al-Dimisyqiy, 2000., Tafsir al-Qur'an al-Azhim, Kairo: Mu'assasah Qurthubah

Jalaluddin Abdurrahman al-Suyuthi , 1994, Jami' al-Ahadits, Beirut: Dar al-Fikr

Muhammad Abu Zahrah, Ushul al-Fiqh, Dar al-Fikr al-'Arabiy

Muhammad al-Ghazali, Qadza'if al-Haqq, 1991, Dimisyqa: Dar alQalam

Muhammad bin 'Alawiy al-Malikiy al-Hasaniy, tt, al-Madh alNabawiy Bayn al-Ghuluwwi wa al-Inshaf, Makkah: Dar Wahdan,

Muhammad bin 'Ali bin Muhammad al-Syaukaniy, 2005, Nail alAuthar min Asrar Muntaqa al-Akhbar, Riyadl-Kairo: Dar Ibn al-Qayyim-Dar Ibn 'Affan

Muhammad bin Husain al-Jizaniy, 2010, Manhaj al-Salaf fi al-Jam'i bayn al-Nushush wa al-Maqashid wa Tathbiqatuha alMua'ashirah, Riyadl: al-Mamlakah al-'Arabiyyah alSa'udiyyah Wizarah al-Ta'lim al-'Aliy

Muhammad Dliya' al-Rahman al-A'zhamiy, 2001, al-Minnah alKubra Syarh wa Takhrij al-Sunan al-Shughra, Riyadl: Maktabah al-Rusyd

Muhammad Ghazali, 2005, 'Aqidah al-Muslim, Mesir: Dar Nahdlah

Muhammad Khalil Harras, tt, Syarh al-'Aqidah al-Wasathiyyah li Syaikh al-Islam Ibni Taymiyyah, (Kairo: Dar al-I'tisham 
Muhammad Nashiruddin al-Albaniy, 1422 H, Sual wa Jawab Haula Fiqh al-Waqi', (Oman-Urdun: al-Maktabah alIslamiyyah

Muhammad Nawawi al-Jawiy, tt, Syarh Maraqiy al-'Ubudiyyah 'ala Matn Bidayah al-Hidayah, Surabaya: al-Hidayah,

Muhammad Shiddiq Hasan Khan al-Qanuji, 1404 H y, Quthf alTsamri fi Bayan 'Aqidah Ahli al-Atsar, tk.: tp

Sayyid Quth, 2004, Fi Zhilal al-Qur'an, Kairo: Dar al-Syuruq,

Sulaiman bin Muhammad bin 'Umar, 1996, Hasyiyah al-Bujairimiy 'ala al-Khathib, Beirut: Dar al-Kutub al-Ilmiyyah

Wahbah al-Zuhailiy, 1985, al-Fiqh al-Islamiy wa Adillatuh, Dimisyqa: Dar al-Fikr.

al-Fikr

1986, Ushul al-Fiqh al-Islamiy, Dimisyqa: Dar , 2002, Tajdid al-Fiqh al-Islamiy, dalam Tajdid alFiqh al-Islamiy, Beirut: Dar al-Fikr

Yusuf al-Qardlawiy, 1977, al-Khashaish al-'Aammah li al-Islaam, Kairo: Maktabah Wahbah

, 1997, al-Halal wa al-Haram, Kairo: Maktabah Wahbah.

, 1999, al-Fiqh al-Islamiy Bayna al-Ashalah wa al-Tajdid, Kairo: Maktabah Wahbah 